\title{
POLYPLOIDY INDUCTION IN Physalis alkekengi
}

\author{
INDUÇÃO DE POLIPLOIDIA EM Physalis alkekengi
}

\section{Gustavo C SANTOS ${ }^{1}$; Felipe P CARDOSO ${ }^{2}$; Adalvan D MARTINS ${ }^{3}$; Filipe A RODRIGUES $^{3}$; Moacir PASQUAL ${ }^{4}$; Paulo C OSSANI ${ }^{5}$; José Magno Queiroz LUZ ${ }^{6}$; Renata A L S REZENDE Joyce Dória R SOARES ${ }^{4}$}

1. Doutor em Botânica Aplicada, Universidade Federal de Lavras - UFLA, Lavras, Minas Gerais, MG, Brasil; 2. Mestrando em Genética, UFLA; 3. Pós-doutorando em Agronomia/Fitotecnia, UFLA; 4. Professor DAG/UFLA; 5. Doutorando em Estatística, UFLA; 6. Professor Universidade Federal de Uberlândia - UFU, Uberlândia, MG, Brasil; 7. Doutora em Agronomia/Fitotecnia, UFLA.

\begin{abstract}
Physalis alkekengi is an ornamental plant that can also be used as a medicinal plant due to its anti-inflammatory, bactericidal, antitumor and fungicidal properties. Polyploidization can be an important tool in the genetic improvement of this species. The objective this work was to obtain tetraploids in vitro and to evaluate the phytotechnical traits of $P$. alkekengi. For this, nodal segments of $P$. alkekengi var. Franchettii were inoculated into petri dishes containing $100 \mathrm{ml}$ of MS medium supplemented with colchicine at concentrations $0 ; 0.04 ; 0.08 ; 0.12$; and $0.16 \%$ and kept in the dark for 24 and $48 \mathrm{~h}$. After the respective treatment periods with colchicine the segments were inoculated into test tubes. The tetraploids were identified by flow cytometry and classical cytogenetics. In vitro seedlings were measured: root length, nodal segment length, leaflet number and total leaf area. In the acclimatization phase, the area of the second leaf and total leaf, petiole radius, stem length, fruit weight with calyx, without calyx, fruit diameter, number of seeds and brix of the pulp were evaluated. Chlorophyll a, chlorophyll b, total chlorophyll, total carotenoid, total chlorophyll / total carotenoid ratio and chlorophyll a / $\mathrm{b}$ ratio were also estimated. The treatment that most produced tetraploid seedlings was with $0.08 \%$ colchicine per $24 \mathrm{~h}$. No significant difference was observed in 7 (seven) variables, these being all variables of photopigments, stem diameter (steam) and brix. In general, diploid (2x) plants were better in 9 (nine) while tetraploid seedlings were better in 6 (six) of the phytotechnical variables. It was concluded that the MS medium supplemented with $0.08 \%$ colchicine for $24 \mathrm{~h}$ allowed $P$. alkekengi tetraploides to be obtained with better phytotechnical qualities.
\end{abstract}

KEYWORDS: Anti-mitotic. Tetraploid. Myxoplasia. Tissue culture. Physalis.

\section{INTRODUCTION}

Physalis alkekengi is a plant of the family Solanaceae that can be easily identified by an additional chalice of bright orange color covering the small fruit and by flowers with white and lobed corolla (WANG et al., 2014). The main varieties are alkekengi and franchetii, the latter with larger fruits and with distinct spots at the base (WANG, 2014). The main application of the franchetii variety is ornamental (POPA-MITROI et al., 2012), but there is a growing interest in its medicinal application due to its anti-inflammatory (HONG, 2015) bactericidal properties (ZHANG, 2016), antitumor (LI et al., 2014) and fungicides (TORABZADEH; PANAHI, 2013).

Polyploidization in plants is a phenomenon that occurs naturally and is important for sympatric speciation (ARVANITIS et al., 2010). Approximately $70 \%$ of the spermatophytes are tetraploids (ZHANG et al., 2012). Biotechnologically, there are several protocols for polyploidization, and their in vitro realization is an excellent way to obtain tetraploid clones and to evaluate them always maintaining a copy (OLIVEIRA et al., 2013). Their occurrence may result in characteristics beneficial to the plant such as drought tolerance (MANZANEDA et al., 2012). Polyploidy also leads to changes in the anatomical and phytotechnical characteristics of the plants (TAVAN; MIRJALILI ; KARIMZADEH , 2015).

In the pharmacological area, polyploidization may increase the production of substances of interest by plants (MAJDI et al., 2010). For example, chromosome duplication led to increased synthesis of wedelolactone in Eclipta alba L (SALMA et al., 2018). Wedelolactone is a plantderived natural product synthesized mainly by plants from Asteraceae family, that displays antihepatotoxic effect in liver cells, block androgen receptor function, inhibit polymerase activity of hepatitis $\mathrm{C}$ virus and it's a candidate drug for prevention as well as treatment of inflammatory diseases and cancer (SARVESWARAN; GAUTAM; GHOSH., 2012). Other medicinal compound is the artemisinin in Artemisia annua. 
(XIA et al., 2018), an antimalarial drug (KHERA; MUKHERJEE, 2019). Another good example is tetrahydrocannabinol in Cannabis sativa (MANSOURI; BAGHERI, 2017) that has many medicinal effects like hypothermia, antinociception, sedation and catalepsy (BANISTER et al., 2019).

There is growing interest in identifying and developing new genotypes of Physalis with different objectives. It is known that in $P$. peruviana, the degree of ploidy interferes in the resistance to the phytopathogenic fungus of the genus Fusarium (LIBERATO et al., 2014; OSORIO-GUARÍN et al., 2016). In $P$. ixocarpa, there are studies comparing the fruit quality of diploid and tetraploid plants (RAMÍREZ-GODINA et al., 2013).

The objective was to obtain tetraploids of $P$. alkekengi var. Franchetii and evaluates them for in vitro and ex vitro plant characteristics.

\section{MATERIAL AND METHODS}

\section{Obtaining biological material}

Seeds of $P$. alkekengi var. Franchetii went through asepsis with $70 \%$ alcohol for $10 \mathrm{~min}, 50 \%$ sodium hypochlorite for $20 \mathrm{~min}$ and four washes with autoclaved distilled water. The seeds were germinated in vitro in MS medium (MURASHIGE; SKOOG, 1962) without growth regulators, at an average temperature of $25 \pm 2 \circ \mathrm{C}$, with a translucent plastic lid, in a growth room with photoperiod $16 \mathrm{~h}$, white fluorescent lamps and 35 $\mu \mathrm{mol} \mathrm{m} \mathrm{m}^{-2} \mathrm{~s}^{-1}$ of irradiance. Seedlings underwent three subcultures under the same conditions.

The adult plants were obtained by acclimatization of the respective treatments induced in vitro in a pot of $25 \mathrm{~L}$ containing Plantmax substrate, in a greenhouse with black photoconverter mesh Cromatinet ${ }^{\circledR}$ Polysack $50 \%$ shading. The spacing between the vessels was $20 \mathrm{~cm}$. The experiment was carried out at the Tissue Culture Laboratory, at the Federal University of Lavras, in the city of Lavras, in the state of Minas Gerais, Brazil. The region is located at latitude $21^{\circ} 14 ' 43$ South, longitude $44^{\circ} 59^{\prime} 59$ West and at an altitude of 918 meters (DANTAS; CARVALHO; FERREIRA, 2007). Ex vitro growth occurred in June, July and August 2017, in which historical temperatures range from 12 to $19{ }^{\circ} \mathrm{C}$ (ACCUWHEATHER, 2017).

\section{Experimental treatment: induction of polyploidy in vitro}

After the third subculture, seedlings were separated for induction of polyploids. Nodal segments of $P$. alkekengi var. Franchettii were inoculated into petri dishes containing $100 \mathrm{ml}$ of MS medium (MURASHIGE; SKOOG, 1962) supplemented with filtered and sterilized colchicine at $0,0.04 ; 0.08 ; 0.12$; and $0.16 \%$ and kept in the dark for 24 and $48 \mathrm{~h}$. Thus, 10 treatments $(5$ concentrations $\times 2$ times in colchicine) were performed. For each treatment 50 nodal segments were used, totaling 500 segments. After the respective treatment periods with colchicine, the explants underwent triple washing in distilled and autoclaved water. The segments were then inoculated into test tubes, under the same micropropagation conditions as mentioned above.

\section{Flow cytometry analyzes}

After 30 days of in vitro growth, the amount of possible mixoploids, diploids and tetraploids was estimated by estimating the amount of DNA by flow cytometry. For this, approximately 50 to $60 \mathrm{mg}$ of young $P$. alkekengi var. Franchettii leaflets were used per treatment, along with corresponding sample of internal reference standard, tomato (Solanum lycopersicum cv. Stupické). The material was ground with a scalpel in a Petri dish containing $1 \mathrm{~mL}$ of ice-cold Marie buffer to release the nuclei (DOLEZEL; BINAROVA; LUCRETTI, 1989). The core suspension was aspirated and subsequently filtered through $50 \mu \mathrm{m}$ mesh filters. The cell suspension was kept in a container with crushed ice so that no deterioration of the material occurred. The nuclei were then stained by the addition of 25 $\mu \mathrm{l}$ of propidium iodide in each sample. Five thousand nuclei were analyzed for each sample, with three replicates. The analysis was performed on the FACSCalibur four-color cytometer (Becton Dickinson) and the histograms obtained and analyzed in the Cell Quest software. The nuclear (pg) DNA content of the plants was estimated by comparison with the position relative to the G1 peak of the internal reference standard.

\section{Cytogenetic analysis}

Root tips $1 \mathrm{~cm}$ long were pre-treated with $0.002 \mathrm{M}$ 8-hydroxyquinoline (8-HQ) for $24 \mathrm{~h}$ at $4^{\circ}$ C (GUERRA, SOUZA, 2002). Roots were fixed in Carnoy 3: 1 (ethanol / acetic acid v/ v) for 24 hours and then stored at $-20^{\circ} \mathrm{C}$. Slides were prepared according to the crushing technique and stained with $2 \%$ Giemsa stain. For the capture of the images a Olympus BX 60 microscope equipped with a Canon A630 camera was used.

\section{Phytotechnical analyzes}

For in vitro seedlings, the length of the root $(\mathrm{cm})$, the length of the nodal segment $(\mathrm{cm})$, and the 
number of leaflets were measured with the aid of a pachymeter. It was also evaluated the total leaf area $\left(\mathrm{cm}^{2}\right)$ with the use of desktop scanner and imageJava image processing and analysis software ImageJ version $1.49 \mathrm{p}$. In the adult plants, acclimatization phase, total leaf area $(\mathrm{cm} 2)$ and second leaf $(\mathrm{cm} 2)$ were evaluated. The petiole radius of the second leaf $(\mathrm{mm})$ and the stem length (cm) were also measured. In the reproductive part, the weight of the fruit was measured with the calyx (g) and without the calyx (g), fruit diameter ( $\mathrm{mm}$ ), number of seeds and brix of pulp (\%).

\section{Statistical analysis}

The experiment was installed in a completely randomized design, with 5 (five) replicates and 10 plants each replicate. The results of the Scott-Knott test (5\% probability) were obtained through the development of scripts in the $\mathrm{R}$ software (R CORE TEAM, 2017) through the package for public use ExpDes.pt package version 1.1.2. (FERREIRA; CAVALCANTI; NOGUEIRA, 2013).

\section{RESULTS}

Four types of seedlings were obtained: nonsurvivors, mixoploids $(2 \mathrm{x}+4 \mathrm{x})$, diploids $(2 \mathrm{x})$ and tetraploids (4x) (Figure 1, Figure 2). Table 1 shows that the treatment that most produced tetraploid seedlings was with $0.08 \%$ colchicine, for $24 \mathrm{~h}$. Nonsurviving seedlings showed necrosis with the treatments. The mixoploid seedlings presented irregular development, deformations and necrotic tissues that were easily visible in the aerial part (Figure 1). The diploid and tetraploid seedlings presented healthy development, being the tetraploids more robust and with larger leaves.

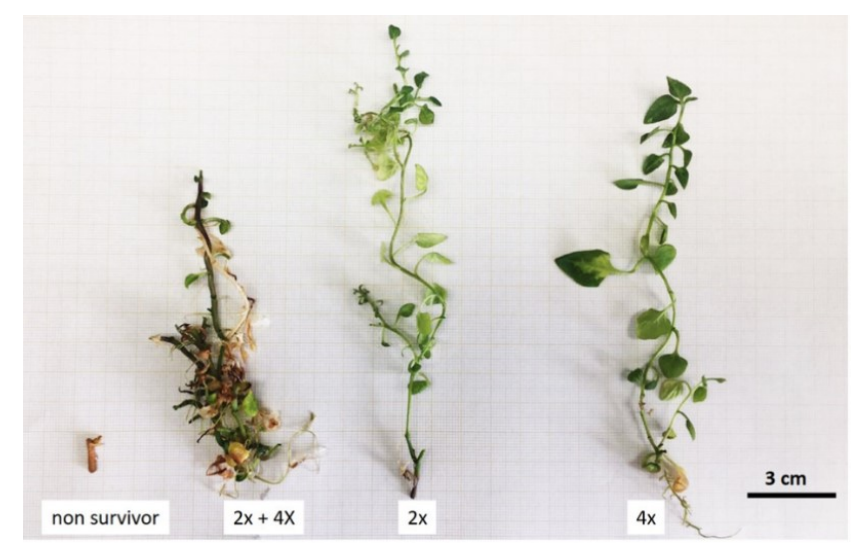

Figure 1. Seedlings of $P$. alkekengi var. Franchettii treated with colchicine.

Non-surviving seedlings (ns), mixoploids $(2 \mathrm{x} 4 \mathrm{x})$, diploids $(2 \mathrm{x})$ and tetraploids $(4 \mathrm{x})$ were obtained.
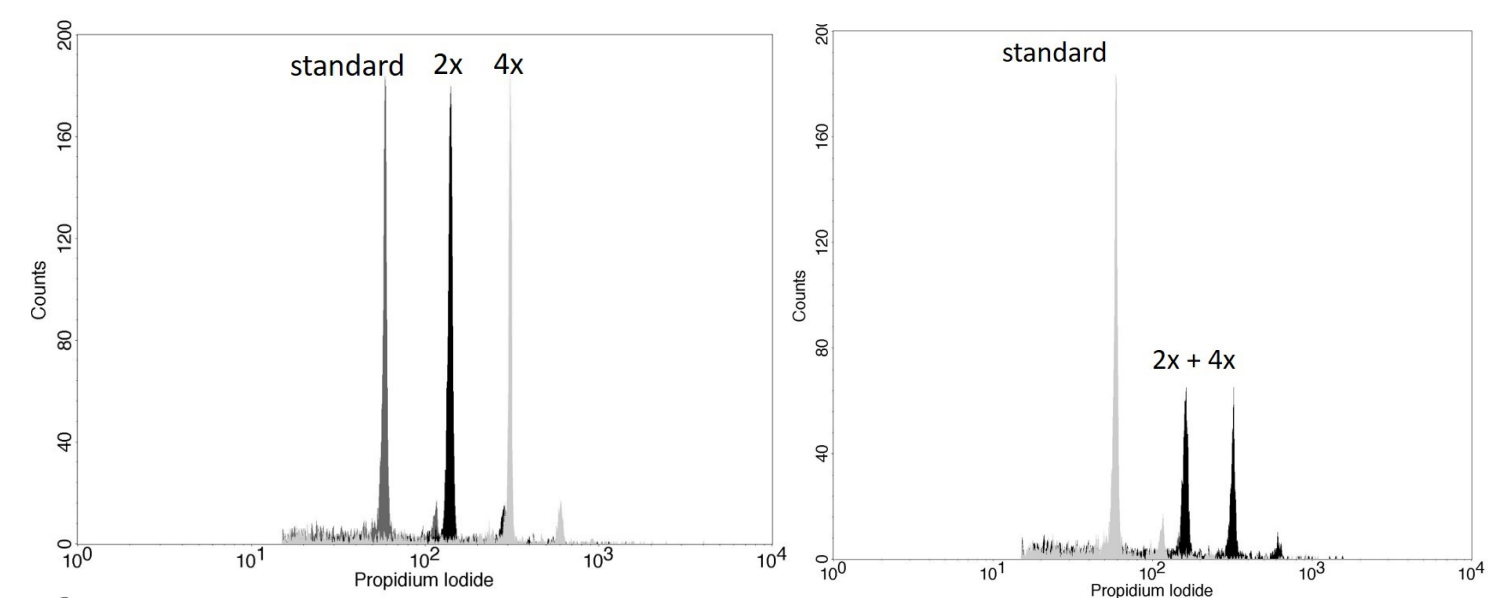

Figure 2. Histograms of flow cytometry for P. alkekengi var. Franchettii mixoploides $(2 \mathrm{x}+4 \mathrm{x})$, diploids $(2 \mathrm{x})$ and tetraploids $(4 \mathrm{x})$ and standard (tomato).

UFLA, Lavras, MG, Brazil, 2017.

Survival and ploidy estimated by cytometry were evaluated (Table 1). The survival of the explants was $100 \%$ in the treatments with $0 \%$ conchicine and decreased as the concentration of the antimitotic was increased. In addition, it was observed that exposure time of $48 \mathrm{~h}$ resulted in 
higher mortality of explants than $24 \mathrm{~h}$ for all treatments with colchicine (Table 1). The DNA content estimated by flow cytometry was practically double in the tetraploid seedlings in relation to the diploids (Table 1).

Table 1. Percentage of survival, number of seedlings for each ploidy obtained in $P$. alkekengi var. Franchettii and DNA content for diploids and tetraploids.

\begin{tabular}{llllll}
\hline $\begin{array}{l}\text { Colchicine } \\
(\%)\end{array}$ & Time (h) & Survival (\%) & $2 \mathrm{x}$ & $4 \mathrm{x}$ & $2 \mathrm{x}+4 \mathrm{x}$ \\
\hline 0 & 24 & 100 & 50 & 0 & 0 \\
\hline 0,04 & 100 & 50 & 0 & 0 \\
\hline 0,08 & 24 & 72 & 24 & 3 & 9 \\
& 48 & 44 & 18 & 2 & 2 \\
\hline 0,12 & 24 & 66 & 13 & 8 & 12 \\
& 48 & 18 & 3 & 5 & 2 \\
\hline 0,16 & 32 & 4 & 5 & 7 \\
& 48 & 12 & 0 & 5 & 7 \\
\hline DNA content (pg) & 12 & 4 & 0 & 2 \\
\hline CV (\%) relative to cytometric analysis & 6 & 1 & $10,46 \mathrm{a}$ & - \\
\hline
\end{tabular}

Legend: $2 \mathrm{x}=$ diploid, $4 \mathrm{x}=$ tetraploid, $2 \mathrm{X}+4 \mathrm{X}=$ myxoploid.

Means followed by the same letter do not differ by $5 \%$ probability.

By the mean test, no significant difference was observed in 7 (seven) variables, all of them being photopigments, stem diameter (steam) and brix (Table 2). In general, diploid (2x) plants were better in 9 (nine) while tetraploid seedlings were better in 6 (six) of the phytotechnical variables. However, of the variables analyzed in vitro, $4 x$ presented greater leaflet number and total leaflet area, while $2 \mathrm{x}$ was better at shoot and radicle length.

Table 2. Analyses of variance (Scott-Knott test) for variables analyzed in diploid (2X) and tetraploids (4X) obtained by colchicine clone explants and adult clone plants of $P$. alkekengi var. Franchettii.

\begin{tabular}{|c|c|c|c|c|c|}
\hline Ploidy & Leaflet Number & Shoot (cm) & Radicle (cm) & Segment $(\mathrm{cm})$ & $\begin{array}{l}\text { Total Leaflet Area } \\
\left(\mathrm{cm}^{2}\right)\end{array}$ \\
\hline $2 \mathrm{X}$ & $8,00 \mathrm{~b}$ & $17,56 \mathrm{a}$ & $6,22 \mathrm{a}$ & $3,84 \mathrm{a}$ & $5,86 \mathrm{~b}$ \\
\hline $4 X$ & $11,00 \mathrm{a}$ & $12,76 \mathrm{~b}$ & $4,66 \mathrm{~b}$ & $1,76 \mathrm{~b}$ & $10,60 \mathrm{a}$ \\
\hline $\begin{array}{l}\mathrm{CV} \\
(\%)\end{array}$ & 11,77 & 6,94 & 11,59 & 7,82 & 11,38 \\
\hline Ploidy & $\begin{array}{l}\text { Total Leaf Area } \\
\left(\mathrm{cm}^{2}\right)\end{array}$ & Leaf Area $\left(\mathrm{cm}^{2}\right)$ & Petiole Ray (mm) & Leaf Number & Stem $(\mathrm{cm})$ \\
\hline $2 \mathrm{X}$ & $772,44 \mathrm{a}$ & $27,84 \mathrm{~b}$ & $2,60 \mathrm{~b}$ & $40,00 \mathrm{a}$ & $15,40 \mathrm{~b}$ \\
\hline $4 X$ & $304,64 \mathrm{~b}$ & $58,96 \mathrm{a}$ & $3,40 \mathrm{a}$ & $8,20 \mathrm{~b}$ & $21,20 \mathrm{a}$ \\
\hline $\begin{array}{l}\mathrm{CV} \\
(\%)\end{array}$ & 0,89 & 7,88 & 18,26 & 5,25 & 3,74 \\
\hline
\end{tabular}




\begin{tabular}{lllllll}
\hline Ploidy & $\begin{array}{l}\text { Stem Ray } \\
(\mathrm{mm})\end{array}$ & $\begin{array}{l}\text { First } \\
(\text { days })\end{array}$ & $\begin{array}{l}\text { Flowering } \\
(\mathrm{g})\end{array}$ & $\begin{array}{l}\text { Fruit with Chalice } \\
\text { Fruit } \\
\text { Chalice }(\mathrm{g})\end{array}$ & $\begin{array}{l}\text { without } \\
\text { Fruit } \\
(\mathrm{mm})\end{array}$ & Diameter \\
\hline $2 \mathrm{X}$ & $5,00 \mathrm{a}$ & $32,60 \mathrm{~b}$ & $2,28 \mathrm{a}$ & $1,78 \mathrm{a}$ & $14,20 \mathrm{a}$ & \\
$4 \mathrm{X}$ & $5,12 \mathrm{a}$ & $61,60 \mathrm{a}$ & $1,11 \mathrm{~b}$ & $0,78 \mathrm{~b}$ & $10,20 \mathrm{~b}$ & \\
\hline $\mathrm{CV}$ & 4,98 & 7,22 & 32,31 & 36,27 & 10,69 \\
$(\%)$ & & & & \\
\hline
\end{tabular}

\begin{tabular}{lll}
\hline Ploidy & Brix (\%) & Seeds Number \\
\hline $2 \mathrm{X}$ & $14,94 \mathrm{a}$ & $187,80 \mathrm{a}$ \\
$4 \mathrm{X}$ & $13,10 \mathrm{a}$ & $29,40 \mathrm{~b}$ \\
\hline CV & \multirow{2}{*}{9,32} & 8,43 \\
\hline$\%)$ & & \\
\hline
\end{tabular}

UFLA, Lavras, MG, Brazil, 2017; Means followed by the same letter do not differ by $5 \%$ probability.

Regarding the adult plant (Figure 3A), 4x took longer to bloom and had a longer root length. Adult diploid plants presented heavier fruits, both with capsule and without capsule, larger fruits and with greater number of seeds (Figures $3 \mathrm{~B}$ and $\mathrm{C}$ ).
Cytogenetic analysis confirmed polyploidization (Figura 4), in which diploid plants showed 24 chromosomes and tetraploid plants showed 48 chromosomes.
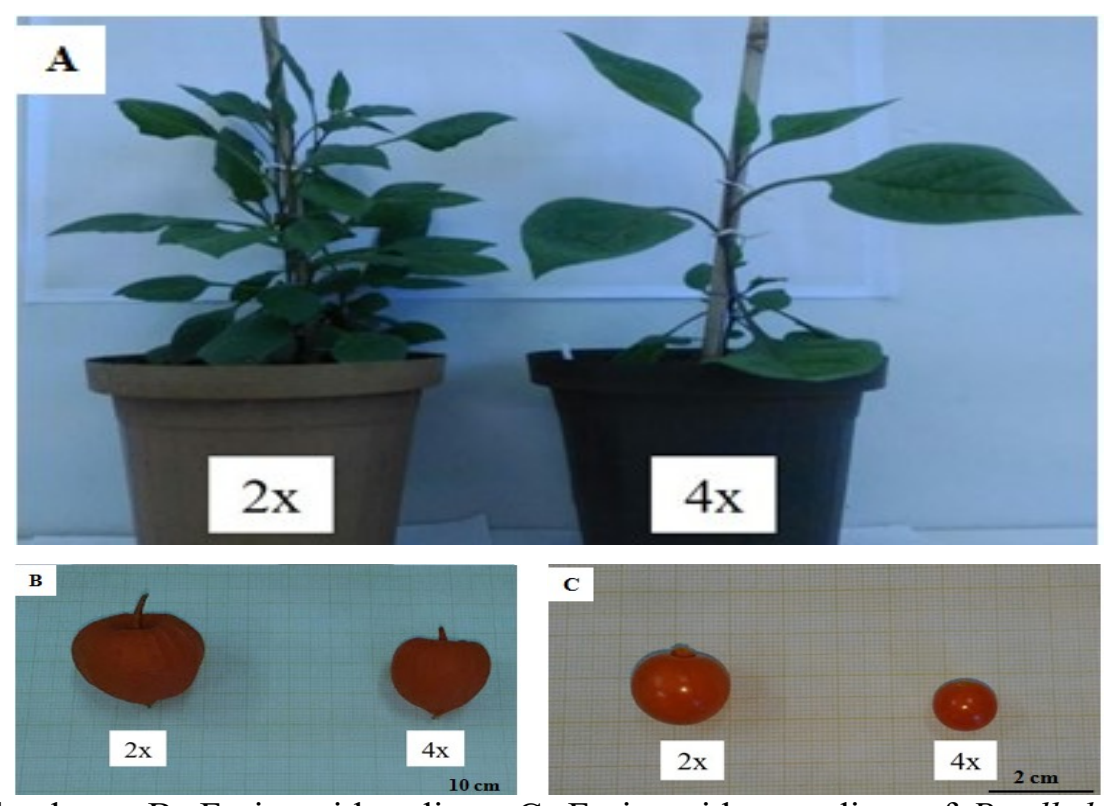

Figure 3. A: Adult plants; B: Fruits with calisse; C: Fruits without calisse of P. alkekengi var. Franchettii diploid $(2 \mathrm{x})$ and tetraploid $(4 \mathrm{x})$.

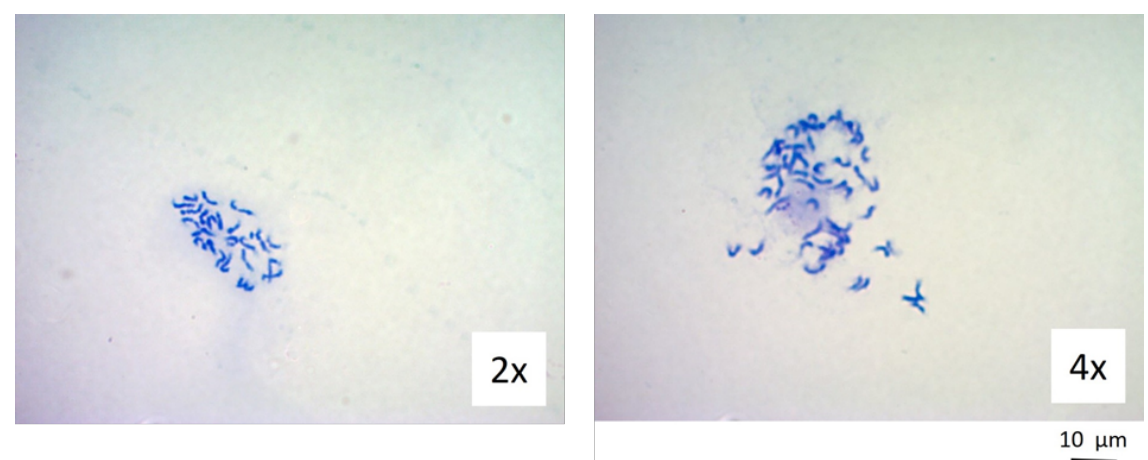

Figure 4. Chromosomes Photography for P. alkekengi var. Franchettii diploides (2x) and tetraploids (4x), respectively with 24 and 48 chromosomes.

\section{DISCUSSION}


As far as we know, the first work of polyploidization of this species was done by Nakamura, Matsuo and Ooyabu (2007), available in japanese language. So this is the first English language work on polyploidization by Physalis alkekengi var. Franchettii.

The best treatment to obtain tetraploids was with $0.08 \%$ colchicine in the MS medium for $24 \mathrm{~h}$, in which 8 tetraploids were observed (Table 1, Figure 1). With this result, it was possible to halve the time of obtaining tetraploids of $P$. alkekengi in comparison to Nakamura, Matsuo and Ooyabu (2007). This reduction in tetraploid obtainment time may be the result of the use of nodal segments instead of the apical buds used by Nakamura, Matsuo and Ooyabu (2007). This result also shows that the excess tissue did not hinder the action of the drug on the apical meristem of the plant.

The appearance of mixoploids was also observed (Table 1, Figure 1). To avoid the appearance of this type of mutant, it would be necessary to use cell suspension for treatment with colchicine, after all polyploidization performed on a single cell generates an individual with all their cells being equally polyploid, unless some cells reject surplus chromosomes (ACANDA; REY; TRONCOSO, 2015). As expected in relation to DNA content, tetraploid seedlings presented twice as much genetic material as diploids (Table 1, Figure 2). The flow cytometry plot shows the G2 peak of the diploid coinciding with the G1 peak of the tetraploid (Figure 2), indicating that chromosome duplication was successful. As expected, $P$. alkekengi diploides seedlings have 24 chromosomes (BADR et al., 1997) and tetraploids 48 (Figure 5).

As observed by Nakamura, Matsuo and Ooyabu (2007), the P. alkekengi var. Franchettii. diploid plants of this experiment also showed higher fruits, higher number of seeds, higher number of leaves (Table 2). However, the results showed that tetraploid plants tend to invest more energy in leaf size (Table 2). One explanation may be the delay to early flowering and fruiting in relation to diploid plants (Table 2). However, molecular and ecological studies must be carried out to discover the advantages of this variety of $P$. alkekengi tetraploid with such characteristics. Tetraploid seedlings may produce more medicinal substances than diploids (JESUS-GONZALEZ; WEATHERS, 2003; SALMA et al., 2018; WEATHERS, 2003; XIA et al., 2018). In other cases, tetraploids may be more tolerant to abiotic stresses (SALE et al., 2008; LIU et al., 2011). Negative changes may also occur. For example, there are tetraploids that develop invasive growth relative to the diploid variety (SCHLAEPFER; EDWARDS; BILLETER, 2010).

In both the results of this experiment and those of Nakamura, Matsuo and Ooyabu (2007), it was observed that the tetraploids of $P$. alkekengi present many anatomical characteristics of smaller size than that observed in the diploid plants (Table 2, Figure 3, Figure 4). These results are the opposite of what is expected in tetraploid plants, which usually show an increase of the organs by the "gigas" effect. The explanations for these results would be the reduction of the number of cell divisions and lower growth rate (SATTLER; CARVALHO; CLARINDO, 2016). This decrease in fruit size reduces the food interest of the obtained tetraploids. In contrast, the main application of $P$. alkekengi is ornamental, an area that also values flowers and fruits of smaller size.

\section{CONCLUSION}

MS medium supplemented with $0.08 \%$ colchicine for $24 \mathrm{~h}$ allowed to obtain $P$. alkekengi tetraploides. However, the tetraploid seedlings presented fewer leaves, smaller fruits and fewer seeds.

RESUMO: Physalis alkekengi é uma planta ornamental que também pode ser usada como planta medicinal devido às suas propriedades anti-inflamatórias, bactericidas, antitumorais e fungicidas. A poliploidização pode ser uma ferramenta importante para o melhoramento genético dessa espécie. O objetivo deste trabalho foi obter tetraplóides in vitro e avaliar as características fitotécnicas de P. alkekengi. Para isso, segmentos nodais de $P$. alkekengi var. Franchettii foram inoculados em placas de Petri contendo $100 \mathrm{ml}$ de meio MS suplementado com colchicina nas concentrações $0 ; 0,04 ; 0,08 ; 0,12 ;$ e $0,16 \%$ e mantido no escuro por 24 e 48h. Após os respectivos períodos de tratamento com colchicina, os segmentos foram inoculados em tubos de ensaio. Os tetraplóides foram identificados por citometria de fluxo e citogenética clássica. As plântulas in vitro foram medidas: comprimento da raiz, comprimento do segmento nodal, número de folhetos e área foliar total. Na fase de aclimatação foram avaliadas a área da segunda folha e área foliar total, raio do pecíolo, comprimento do caule, peso do fruto com cálice, sem cálice, diâmetro do fruto, número de sementes e brix da polpa. Também foram estimadas clorofila a, clorofila b, clorofila total, carotenóides totais, razão clorofila total / 
carotenóide total e razão clorofila a / b. O tratamento que mais produziu mudas tetraplóides foi com colchicina a $0,08 \%$ por 24 horas. Não foi observada diferença significativa em 7 (sete) variáveis, sendo todas variáveis de fotopigmentos, diâmetro do caule (vapor) e brix. Em geral, as plantas diplóides (2x) foram melhores em 9 (nove) variáveis fitotécnicas, enquanto as mudas tetraplóides foram melhores em 6 (seis). Concluiu-se que o meio MS suplementado com colchicina a $0,08 \%$ por $24 \mathrm{~h}$ permitiu obter tetraploides de $P$. alkekengi com melhores qualidades fitotécnicas.

PALAVRAS-CHAVE: Anti-mitótico. Tetraploide. Mixoplasia. Cultura de tecidos. Physalis.

\section{REFERENCES}

ACANDA, Y.; REY, M.; TRONCOSO, O. M. Highly efficient in vitro tetraploid plant production via colchicine treatment using embryogenic suspension cultures in grapevine (Vitis vinifera cv. Mencía). Plant Cell, Tissue and Organ Culture, v. 123, n. 3, p. 547-555, 2015. https://doi.org/10.1007/s11240-015-0859-3 ACCUWHEATHER. Disponível em: <www.accuweather.com>. Acessado em: 25/11/2017.

ARVANITIS L.; WIKLUND, C.; MÜNZBERGOVA, Z.; DAHLGREN, J. P.; EHRLÉN, J. Novel antagonistic interactions associated with plant polyploidization influence trait selection and habitat preference. Ecology Letters, v. 13, n. 3, p. 330-337, 2010. https://doi.org/10.1111/j.1461-0248.2009.01429.x

BADR, A.; KHALIFA, S. F.; ABOEL-ATTA, A. I.; ABOU-EL-ENAIN, M. M. Chromosomal criteria and taxonomic relationships in the Solanaceae. Cytologia, v. 62, n. 2, p. 103-113, 1997.

https://doi.org/10.1508/cytologia.62.103

BANISTER, S. D.; ARNOLD, J. C.; CONNOR, M.; GLASS, M.; MCGREGOR, I. S. Dark Classics in Chemical Neuroscience: $\Delta$ 9-Tetrahydrocannabinol. American Chemical Society Chemical Neuroscience, $v$. 10, n. 5, p. 2160-2175, 2019. https://doi.org/10.1021/acschemneuro.8b00651

DANTAS, A. A. A.; CARVALHO, L. G.; FERREIRA, E. Climatic classification and tendencies in Lavras region, MG. Ciência e Agrotecnologia, v. 31, n. 6, p. 1862-1866, 2007. https://doi.org/10.1590/S141370542007000600039

DOLEŽEL, J.; BINAROVA, P.; LUCRETTI, S. Analysis of nuclear DNA content in plant cells by flow cytometry. Biologia Plantarum, v. 31, n. 2, p. 113-120, 1989. https://doi.org/10.1007/BF02907241

FERREIRA, E. B.; CAVALCANTI, P. P.; NOGUEIRA D. A. ExpDes.pt: Pacote Experimental Designs (brazilian portuguese). 2013. URL <https://cran.r-project.org/web/packages/ExpDes.pt/index.html>. R package version 1.1.2.

GUERRA, M.; SOUZA, M. J. Como observar cromossomos: um guia de técnicas em citogenética vegetal, animal e humana. Ribeirão Preto: Ed. FUNPEC, 2002. 131p.

HONG, J. M. Anti-inflammatory activities of Physalis alkekengi var. franchetii extract through the inhibition of MMP-9 and AP-1 activation. Immunobiology, v. 220, n. 1, p. 1 - 9, 2015.

https://doi.org/10.1016/j.imbio.2014.10.004

JESUS-GONZALEZ, L. WEATHERS, P. J. Tetraploid Artemisia annua hairy roots produce more artemisinin than diploids. Plant Cell Reports, v. 21, n. 8, p. 809-813, 2003. https://doi.org/10.1007/s00299-003-0587-8

KHERA, A.; MUKHERJEE, R. Artemisinin resistance: Cause for worry? Journal of Marine Medial Society, v. 21, n. 1, p. 4-8, 2019. https://doi.org/10.4103/jmms.jmms_43_18

LI, X.; ZHAO, J.; YANG, M.; LIU, Y.; LI, Z.; LI, R.; LI, X.; LI, N.; XU, Q.; KHAN, I. A.; YANG, S. Physalins and withanolides from the fruits of Physalis alkekengi L. var. franchetii (Mast.) Makino and the 
inhibitory activities against human tumor cells. Phytochemistry Letters, v. 10, n. 1, p. 95-100, 2014. https://doi.org/10.1016/j.phytol.2014.08.004

LIBERATO, S. A.; SANCHEZ, E.; ARGÜELLES, J. H.; GONZÁLEZ, C.; NUNEZ, V.; BARRERO, L. S. Cytogenetic of Physalis peruviana L., and Physalis floridana Rydb. Genotypes with differential response to Fusarium oxysporum. Corpoica Ciencia y Tecnología Agropecuaria, v. 15, n. 1, p. 51-61, 2014. https://doi.org/10.21930/rcta.vol15_num1_art:396

LIU, S.; CHEN, S.; CHEN, Y.; GUAN, Z.; YIN, D.; CHEN, F. In vitro induced tetraploid of Dendranthema nankingense (Nakai) Tzvel. shows an improved level of abiotic stress tolerance. Scientia Horticulturae, v. 127, n. 3, p. 411-419, 2011. https://doi.org/10.1016/j.scienta.2010.10.012

MAJDI, M.; KARIMZADEH, G.; MALBOOBI, M. A.; OMIDBAIGI, R.; MIRZAGHADERI, G. Induction of tetraploidy to feverfew (Tanacetum parthenium Schulz-Bip.): morphological, physiological, cytological, and phytochemical changes. HortScience, v. 45, n. 1, p. 16-21, 2010. https://doi.org/10.21273/HORTSCI.45.1.16

MANSOURI, H.; BAGHERI, M. Induction of Polyploidy and Its Effect on Cannabis sativa L. In:

CHANDRA, S.; LATA, H.; ELSOHLY, M. (Eds). Cannabis sativa L. - Botany and Biotechnology, 1. ed. Oxford: Springer, Cham, 2017. p. 365-383. Avaliable in: https://link.springer.com/chapter/10.1007/978-3-31954564-6_17. Acessed in: 09 out 2019. https://doi.org/10.1007/978-3-319-54564-6_17

MANZANEDA A. J.; REY, P. J.; BASTIDA, J. M.; WEISS-LEHMAN, C.; RASKIN, E.; MITCHELL-OLDS, T. Environmental aridity is associated with cytotype segregation and polyploidy occurrence in Brachypodium distachyon (Poaceae). New Phytologist, v. 193, n. 3, p. 797-805, 2012. https://doi.org/10.1111/j.14698137.2011.03988.x

NAKAMURA, N.; MATSUO, Y.; OOYABU, E. Development of tetraploid Chinese lantern (Physalis alkekengi L.var. franchetii Makino) and its characteristics. Horticultural Research (Japan), v. 6, n. 3, p. 341345, 2007. https://doi.org/10.2503/hrj.6.341

OLIVEIRA, S. C.; NUNES, A. C. P.; CARVALHO, C. R.; CLARINDO, W. R. In vitro polyploidization from shoot tips of Jatropha curcas L.: a biodiesel plant. Plant Growth Regulation, v. 69, n. 1, p. 79-86, 2013. https://doi.org/10.1007/s10725-012-9749-4

OSORIO-GUARÍN, J. A.; ENCISO-RODRÍGUEZ, F. E.; GONZÁLEZ, C.; FERNÁNDEZ-POZO, N.; MUELLER, L. K.; BARRERO, L. S. Association analysis for disease resistance to Fusarium oxysporum in cape gooseberry (Physalis peruviana L). BMC Genomics, v. 17, n. 248, n.p., 2016.

https://doi.org/10.1186/s12864-016-2568-7

POPA-MITROI, D.; POPA-MITROI, G.; NICU, C.; MANDA, M. Study on behavior of Physalis alkekengi L. species in spontaneous flora and culture in order to evaluate its decorative quality. South Westem Journal, v. 3, n. 2, p. 185-202, 2012.

RAMÍREZ-GODINA, F.; ROBLEDO-TORRES, V.; FOROUGHBAKHCH-POURNABAV, R.; BENAVIDES-MENDOZA, A.; HERNÁNDEZ-PIÑERO, J. L.; REYES-VALDES, M. H.; ALVARADOVÁSQUEZ, M. A. Yield and fruit quality evaluation in husk tomato autotetraploids (Physalis ixocarpa) and diploids. Australian Journal of Crop Science, v. 7, n. 7, p. 933-940, 2013.

R CORE TEAM 2017. R: A Language and Environment for Statistical Computing. R Foundation for Statistical Computing, Vienna, Austria. URL http://www.R-project.org.

SALE, B.; ALLARIO, T.; DAMBIER, D.; OLLITRAULT, P.; MORILLON, R. Tetraploid citrus rootstocks are more tolerant to salt stress than diploid. Comptes Rendus Biologies, v. 331, n. 9, p. 703-710, 2008.

https://doi.org/10.1016/j.crvi.2008.06.007 
SATTLER, M. C.; CARVALHO, C. R.; CLARINDO, W. R. The polyploidy and its key role in plant breeding. Planta, v. 243, n. 2, p. 281-296, 2016. https://doi.org/10.1007/s00425-015-2450-x

SALMA, U.; KUNDU, S.; HAZRA, A. K.; ALI, M. N.; MANDAL, N. Augmentation of wedelolactone through in vitro tetraploid induction in Eclipta alba (L.) Hassk. Plant Cell, Tissue and Organ Culture, v. 133, n. 2, p. 289-298, 2018. https://doi.org/10.1007/s11240-018-1381-1

SARVESWARAN, S.; GAUTAM, S. C.; GHOSH, J. Wedelolactone, a medicinal plant-derived coumestan, induces caspase-dependent apoptosis in prostate cancer cells via downregulation of PKC $\varepsilon$ without inhibiting Akt. International Journal of Oncology, v. 41, n. 6, p. 2191-2199, 2012.

https://doi.org/10.3892/ijo.2012.1664

SCHLAEPFER, D. R.; EDWARDS, P. J.; BILLETER, R. Why only tetraploid Solidago gigantea (Asteraceae) became invasive: a common garden comparison of ploidy levels. Oecologia, v. 163, n. 3, p. 661-673, 2010. https://doi.org/10.1007/s00442-010-1595-3

TAVAN, M.; MIRJALILI, M. H.; KARIMZADEH, G. In vitro polyploidy induction: changes in morphological, anatomical and phytochemical characteristics of Thymus persicus (Lamiaceae). Plant Cell, Tissue and Organ Culture, v. 122, n. 3, p. 573-583, 2015. https://doi.org/10.1007/s11240-015-0789-0

TORABZADEH, P.; PANAHI, P. Evaluation of antifungical activity of Physalis alkekegi L. extracts on Microsporum canis, Candida albicans, Trichophyton mentagrophytes and Nocardia asteroids. Middle-East Journal of Scientific Research, v. 13, n. 7, p. 926 - 929, 2013.

WANG, R. A new combination in Alkekengi (Solanaceae) for the flora of China. Phytotaxa, v. 178, n. 1, p. 59 - 60, 2014. https://doi.org/10.11646/phytotaxa.178.1.9

XIA, J.; MA, Y. J.; WANG, Y.; WANG, J. W. Deciphering transcriptome profiles of tetraploid Artemisia annua plants with high artemisinin content. Plant Physiol Biochem, v. 130, n. 1, 130, p. 112-126, 2018. https://doi.org/10.1016/j.plaphy.2018.06.018

ZHANG, M.; ZHANG, Y.; HUANG, J. J.; ZHANG, X.; LEE, M. K.; STELLY, D. M.; ZHANG, H. B. Genome physical mapping of polyploids: a BIBAC physical map of cultivated tetraploid cotton, Gossypium hirsutum L. PLoS One, v. 7, n. 3, p. e33644, 2012. https://doi.org/10.1371/journal.pone.0033644

ZHANG, C. Y. 1H NMR spectroscopy-guided isolation of new sucrose esters from Physalis alkekengi var. franchetii and their antibacterial activity. Fitoterapia, v. 114, n. 1, p. 138-143, 2016.

https://doi.org/10.1016/j.fitote.2016.09.007 